\title{
Social Contract: Sovereign Contracted or Created? - Comparative Analysis Between T. Hobbes and S. Pufendorf
}

\author{
Eriseld Kalemaj \\ University "Fan S. Noli" Korçë, Albania, \\ Faculty of Natural Sciences and Humanities, Department of Social Sciences
}

\begin{abstract}
This paper has in its focus the notion of 'Sovereign'. The discussion will be conducted within the "School of Natural Law", which we will focus on two representatives; Thomas Hobbes and Samuel Pufendorf. Through a comparative philosophical analysis, we are going to stop on the basics, the genesis of sovereign power. Political philosophy in the context of finding the source of sovereign power is a problem in the landmark of the unsolvable. "Scool of Natural Law" referring to the natural condition has the solution to this problem. Compare lines will start from this premise, to know after, how the reason goas towards two different concepts of "Social Contract". Contract which generates sovreigen person, it defines the nature and content of the power of this person. At this discourse, social contract as the core hub of transition, conversion to the state of nature in a civil context is rolling between the political and juridical character. Discussion, which essentially make us know the nature of the relationship between the Sovereign and members of society, sovereign and state, the member of society between each other. In other words, we will see how the political - legal forms of organization, the way of governing is determined by the nature of initial social contract
\end{abstract}

Keywords: state of nature, social contract, sovereign, civil society

\section{Introduction}

Europe of times of Renaissance and Reformation brought foundamental changes, to the forms of thought, lifestyle, sociopolitical organization, etc. In the context of a troubled continent, after the dissolution of the Holy Roman Empire and the birth of the nation state, the notion of "Sovereign" comes naturally as time requirement.

Time which inspired scientific thinking model and approach to problems. Scientific rationality was returning to humanity, to find there the foundamentals and not to the theological principles. In this sense, secular trend in knowledge it was premise to laicise the political power. On the other hand, the decline of domination of the Aristotelian and the fragility philosophy of moral relativism would be another argument - critical to find solid foundamentals, from which the society will be consolidated in the legal and political context. Further, to organize state - nations in mutual and lasting relationship. It is on these terms that was created and developed the thoughts of the school of natural law, which would inspire the modern political discourses.

The problem of Sovereign required secure premises, to justify a higher and strong power with the goal of organizing a sustainable society, Hobbes and Pufendorf (but not only) started from what nature teaches us. Knowledge of human nature and the natural condition of society would be basics, from where we will start a comparative discussion to find the source of sovereign power. The argument which in the context of socio-political organization, will lead to the "Social Contract". The focus will be on understanding them meaning that gives each of them to this act, like direct genereator of the person with sovereign power. With interest, will be the juridico- political model, which comes as the post reality - contract.

\section{Human by nature; law and natural law}

What is the human by nature? In what relations, he stands with others? In the empirical logic of Hobbes, man is seen as a body, as an object among other objects of nature. In other words, man isn't seen differentiated from the natural environment. $\mathrm{He}$ is part of the physical nature and is defined, determined by its nomocracy. Human acting in natural circumstances is 
dictated by the actions of the other objects, which are located outside him. For Hobbes is absurd to think that a man can be put in motion by himself (Tuck, 2008, p. 63). He is seen as a being totally passive and irresponsible for his behavior. The scientific rationality of Hobbes objectivised the natural explanation within the framework of psycho - physical. In this sense, man is seen more as a being naive; perceptive closely related with the direct interest of life (Levitani, 2000, p. 10).

The context of human gullibility and the state of perception is an indication that he follows its natural instinct. The instinct that essentially has factual existence (life). In such circumstances, the human is motivated by the fulfillment of this instinct, regardless of the object. Implying the total lack of regulation, means for Hobbes's that "only the present exists in nature" (Hobbes, 2000, p. 13). Importance has the momentary interest as a direct requirenment of instinct for good and personal pleasure. Here falls the value or interest for the other, no moral or humane principles. Moment, the present is decisive for man in natural conditions, it dictates his behavior and actions, making a completely spontaneous human being and without given rules. The direction of the moment interest, essentially creates conditioned individual by natural requirements, but unimpeded by any other rule or principle to meet these requirements. Good and evil, right and wrong is always seen in the interest of the strongest. This is expressed from the antiquity by sophist Thrasimah (Plato, 1999, p. 26). Precisely here Hobbes gives the understanding of "Natural Law" when he writes: "The natural law ... is freedom of every person to use his power, as he will himself, to preserve its nature, in other words his life and, therefore, do everything according to his judgment and reason, he conceives as the most suitable for this purpose " (Hobbs, 2000, p. 80). In other words, 'natural law' is equivalent to 'absolute freedom', where the primary goal is to ensure the physical existence, and on this purpose any kind of action is more than justified.

The opposite of the right (freedom), for Hobbes is duty (law). Here is distinguished right by law, where the natural right is absolute spontaneity, and the law of nature is the discovery of reason. In this context, the right ". . consists in the freedom to do or not to do something, while the law stipulates and makes mandatory one of the two. So, the law and the right distinguish between them as much as the freedom and responsibility, which are incompatible with each other if they are applied to the same " (Hobbs, 2000, p. 81). Discovering the reason (law) requires binding behavior to do or not to do something which serves to a specific purpose. In the contexts of the natural condition the reason discoveres the natural law, this is unviolation of natural law of another, the right of life. The law of nature is a limitation of the absolute right of human (freedom). Relationship goes in contradiction with each other. Selfish tendence of the human, being perceptive in natural circumstances (without rules), the law of nature is not taken into account at all.

Pufendorf joins the Hobbes's idea that, external factors are often determinant in human behavior. However, otherwise from Hobbes, Pufendorf is dualist in the treatment of human nature. Man, is not just a physical being, but also mental, spiritual (Pufendorf, 2007, p. 75). From this point of view, we see man as a being not totally perceptive, but abstractive. In the judgement of Pufendorf, the human carries by nature minimum reason. If for Hobbes, human is moved by the outside world, from the perception of objects, for Pufendorf's man is more active. Man, by nature has the ability to overcome the constraints imposed by nature. So, he moves not only by external factors, but is motivated by cognitive abilities and will. He creates concepts and analyzes their meaning. How to say, the human depart from himself to act and is not just a physical object, which is set in movement by other objects, as Hobbes thinks. He chooses, without being imposed solely by external circumstances. So, man is author of his behavior, responsible for its actions (Pufendorf, 2007, p. 38).

Dualism of Pufendorf, from what I expressed, opposes the difference that makes Hobess between the "right" and "duty". Reasoning human nature means that the duty or the law is an expression of freedom and not the opposite. Whether in the Hobbes's we find the distinguishment between the duty and the right, as the difference between the law (reason) and liberty (perception), at Pufendorf's we have the expression of freedom as a combination of law and duty. In this sense the human is freedom for Hobbes, only when he is not limited by external factors, whereas for Pufendorf the human, somehow creates freedom as a synthesis between the right and duty, reason and perception.

\section{The relationship of man with man in the natural condition}

In nature, man according to Hobbes requires in complete freedom the fulfillment of private interest, it is characterized by selfishness and unkindness. This means that in the state of nature, man is seen as the enemy of man, he wants to defend himself by fighting or subjected other rivals (Hobbes, 2000, p. 77). Hence, the tendency to gain more power and he who has more power reaches to impose on others. Told in other words, natural human condition it is in a continuous state of 
war, for more force, more power (Hobbes, 2000, p. 61). In this sense man tries to provide an individual power to accomplish essentially his nature, implied here the existence. He has the ability to create and enjoy the Individual power, which is always in function of his private personal interest. Within this force is measured even the freedom. The more power has this person, the less is limited. This is the power given by his ego that is exerted over others in its own interest. This is freedom in the conept of Hobbes, closely related to external factors.

The notion of "protecting themselves"' is as well a central term to Pufendorf, whom identifies it as the strongest impulse of man than any other incentive (Pufendorf, 2007, p. 59). Primary in human nature is itself, unencroachment and maintaining the personal integrity (safety). This fact makes Pufendorf subsequent and sequential of Hobbes theory (Palladini, 2008, $p$. 34). The fact that man bears a distinctive minimum reason, in the judgment of Pufendorf is seen as a task to not affect the Other. Even he realizes that alone is incomplete in nature, which means that "man is not born only for himself. . . " (Pufendorf, 2007, p. 75). Natural tendency to cohabit in the basics has fulfilling itself. The other is a prerequisite for this. In short words, man in all his complexity is "... designed by nature to social life" (Pufendorf, 2007, p. 114). The goal remains the mutual benefit and minimizes damages against each - other (Palladini, 2008, p. 34). Community is consequence of reason, which avoids the distress condition of living in conflict. This is the key difference with Hobbes, where Pufendorf didn't see the man as being extremely selfish and malicious. In the end, minimal reason makes the human to live in community, by featuring a minimal humanity. Humanism, which in the judgment of Hobbes constitutes appearance, the natural conditions of actual circumstances. At the core of this situation is the war, selfishness, conflict, unkindness - towards each other.

\section{The necessity for a power sovereign}

Referring the meaning of the" natural law" according to Hobbes as an absolute freedom, where ". . . everyone has the right to do everything, even over the body of another. So, as long as continue this right of every man to do anything, may not have security for anyone. . " (Hobbs, 2000, p. 81). Hence, naturayl man goes toward finding ways to ensure natural existence. Rivalry, mistrust, greed for power, natural condition of war (chaos) comprise the premise of Hobbes, from where is seen the necessity of a power to change the situation by creating a sustainable social organization.

So, impossible and constantly frightened by the situation of the permanent war in the natural condition (social), man requires solid basis to realize its natural condition. He lifts up from his personal power (from liberty, his absolute right. ) to surrender it to a greater power in function of protecting itself (Hobbs, 2000, p. 61). Somehow it becomes reasonable (is forced) to accept a greater power than every one in particular, but he takes care to build symmetrical relations inside of the society. But which is this power that stands above everyone? Where is it?

"Fear of repression prompted this man to come forward or seek help through friends. Because there is no other way, through which man can secure his life and liberty" (Hobbs, 2000, p. 62). To create stable and reliable reports in order to fulfill the natural law of self-defense, is accepted a government that stands above all. Only in this power we can see in real terms a compact society and deserved to be called like this. Without power, the society is in a situation of conflict, division, confusion, chaos and relativity. Judgments or other arguments on the creation of the human community, in the philosophy of Hobbes seem enough idealistic to be believed. In contrast with Pufendorf, moral for the other is against human nature. Ethical ideal is not valid because by nature man is driven by ego and personal interest.

The common thing here in both authors is, the fundamental law of nature is to achieve peace. However, at Pufendorf the man is reasonable and social being, then, why do we need the sovereign power? People can live in peace and harmony without the need for a power?! So, man will get enough with the sociality, with the natural condition, and another power would be unnecessary, excessively redundant?!

However, for Pufendorf the possibility of evil exists. Indeed, man by nature is unpredictable as human being, creeping, camouflaged, sophisticated in behavior, whom may tend to benefit selfishly in the expense of others and sociality in general. Most of people operate through a conscience acquired by sociality, tradition or social authority. However, this is not enough to think always to think always in the right way. Than, in paranoia circumstances, fear, where the moral of natural sociality is fragile, the man must proceed to protect himself, by referring to a higher power. A power, that takes care for unencroachment of the natural condition of life and sociality. "The conclusion is, to be secure, he needs to be social; which means to join forces with others like him, and to treat them in ways that they don't' bear to have un excuse for harming him. But even to be willing to preserve and encourage the benefits " (Pufendorf, 2007, p. 62). Thus, despite the sociality achieved 
excists the possibility to easily dismantle this condition. Taking the argument of Hobess, the Pufendorf sees the consolidation of natural sociality to the presence of a higher power as a union of individual forces

To this argument, the fear of death is the greater natural bad, for Hobbess as well as for Pufendorf (Pufendorf, 2007, $p$. 61). Exceptt fear and uncertainty, the argument that unites both authors are justification (finding) of sovereign power tat the social community even in different contexts. Hobbes starts from a naive crowd, in a natural condition, while Pufendorf's departs from sociality, where every member carries a minimum reason to cohabit.

At this point of comparison, Hobbes sees man and community as totally terrible, differently from Pufendorf's where the bad is possible in society, not everyone want to affect the state of nature (sociality). Thus, the necessity of a higher power is justified by the possibility of the evil in society and not from the total bad that Hobbes describes. Hobess saw the extinction of moral relativism (social chaos) only to the political power without socialite, while Pufendorf doesn't exclude the reason of social situation but when the situations don't get resolutation by sociality, then we can refer to a higer power. In this moment of discourse, Hobbes creates short link between natural condition (the crowd) and political power, like necessity for drastic change, but Pufendorf, considering sociality as natural condition requires continuation, consolidation of the state of nature in order to avoid violation of natural law of life and sociality as an intermediary condition in realisation of this law.

Here stands clear that the sovereign power is justified over foundamentals of natural condation, but in different contexts. Interesting is the fact that the factors that lead to the necessity of a higher power are fear and uncertainty. This makes people more reasonable, being distanced from the natural law (absolute freedom of Hobbes), and seeking the law, as a guarantee to avoid the bad condition of nature. Guarantee that is given by a higher power means that it is absolute and inviolable. However different contexts of natural condition from both authors will lead us to different absolute meanings of law.

\section{The Social Contract; Contracted power or created power?}

In terms of instability and uncertainty man tends to avoid the risk that comes from moral relativism. This means that he is looking for objectivity behavior. So, he needs harmony and clear rules for himself, but even as expectation for another. Unable to achieve this in terms of individuality, the man requires a higher power, and beyond all. The greatest power that man can have is to unite all individual powers in a single one (Hobbs, 2000, p. 53). So, the greatest power is the unity of all as one body. But how can be achieved this unity?

For both authors, this unity is achieved only through social contract. From the description of natural condition, people are conditioned to enter into agreements with each - other. Pufendorf, 2007, p. 103). But, for what contract we talk about? Hobbes and Pudendorf although are contractualist they share different views for it.

In terms of insecurity and self-defense in the natural condition, everyone understands (is made more reasonable for Hobbes) should enter into agreements with other members. Basically, Hobbes contract means a dacordnes between members of society to authorize someone, as a third party, who acts on everyone. "Contract" and "authorization" have a complementary relationship in the context of the discourse of Hobbes. The authorization is an act of will and responsibility, and the contract as such should be treated as an act of deliberate and conscious. Hence, the social agreement makes the parties responsible contractual, author of its, in contrast of natural condition where the man was totally irresponsible and all his behaviors were legimitated. From this argument, Hobbes issue as a third law the absolute duty to respect the contract, as a personal responsibility (Hobbs, 2000, p 90). Expressed in these terms, Hobbes explores the concept "person" where is talking about actions, that represent him directly, what is called a "natural person", if he represents somebody else would be called "artificial person"

(Hobbs, 2000, p. 101). Precisely here, the term "person" is in the sense of responsibility. Natural person is also the author of his actions, this makes him responsible, and the artificial person is responsible for that which is autorised.

(Contract as willful and conscious act is reached when all powers are focused to a single joint force (Hobbes, 2000, p. 109). So, the contract is an act of authorization which is expressed to the postulate of Hobbes: ".... I I authorize and give up my right of governing myself to this man, or to this assembly of men, on this condition, that thou give up the right to him, and authorize all his actions in like manner" (Hobbs, 2000, p. 109). The members agree not to create a Sovereign but to contract a person, where everyone delegate the power and the right to him. The authorization of the Sovereign power through social contract is not an expression of unconditional abidance, without any sort of benefit. On the contrary, the social contract is 
the mediator of mutual benefit, where for Hobbes equation is; individual give up on freedom and the right, he accepts to obey a higher authority, taking as a guarantee the peace, life and safety. So, the social contract is a form of exchange, where members are willing to give up the natural right (freedom) in function of peace, by accepting a minimum interaction of freedom (Hobbes, 2000, p. 81). Renunciation of freedom, the right to do something in a contractual relationship means that the other should do the same, in the same size. Abandoning the law in this case is the passage of this right to another person (Hobbs, 2000, p. 82). "Whom that carries this person is called sovereign, and is said to have sovereign power, and everyone else is called Citizen" (Hobbs, 2000, p. 109).

So the contract is an act-agreement between all to authorize individually a person with the right of power. Thanks, this pact, the society is created as unity or as a single political body, as a power of all that is given to an artificial person (Sovereign). Creating as a single body, as a political body or united in a state (Civitas). Beyond unity, the contract in the sense of authorization is a link between members, but also an individual link, directly to the Sovereign Person, after he authorize the Sovregin to carry power and his right, whereas, the contract has to do with the agreement that all the members have to do the same. A contract like this provides conviction and avoides the right of rebellion, because after all, in personal responsibility, the individual has authorized someone to subordinate to him. This becomes more often for the fact that the greatest fear of Hobbes is anarchy and chaos.

Rebellion is an expression of this trend, which will lead us again to the poor state of nature, condition which should necessarily be avoided. For this reason, this person is powerful Leviatani with primar aim peace in society and protection of everyone. His power overcomes each special and individual power.

In a schematic way, vieupoint of Hobbes will appear as below:

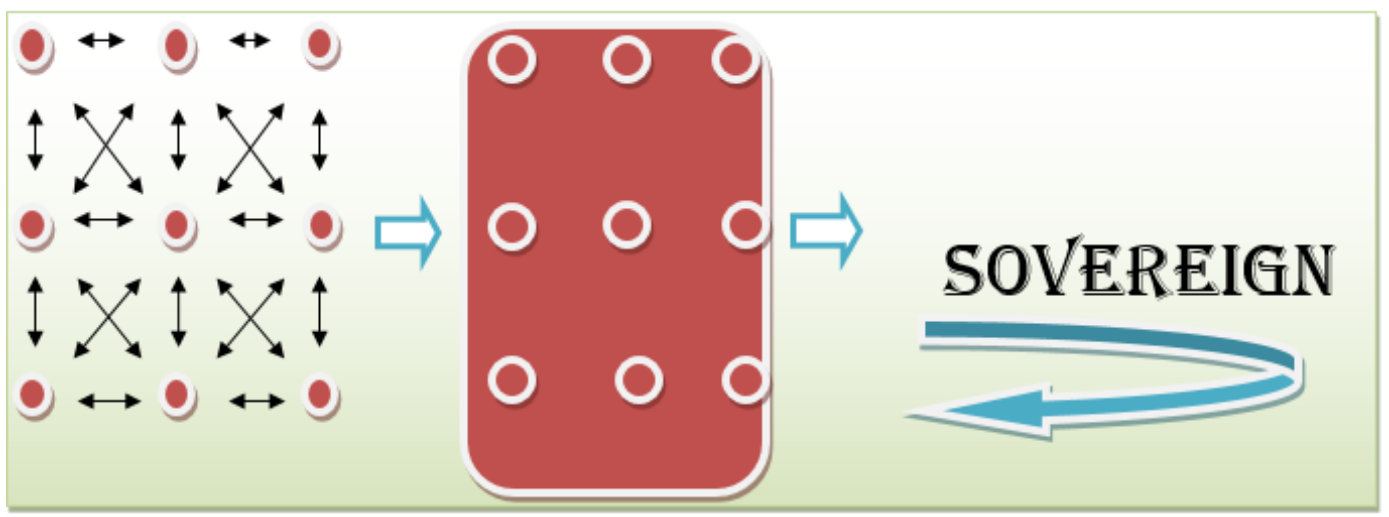

\section{Kontrata shoqërore ( Trupi politik (Civitas) dhe individi i dalluar në të ( Personi Sovran}

\section{Fig. 1}

( All this sematich explanation starts from the socio - political situation (as inductive logic), going to generalization, like it is the Sovregein Person, the bearer of power of all. Sovereign government action is actually deductive logic (juridical properties), where from the personification of all on, act on whole and each in particular. Therefore, the sovereign returns over the subjects and political entities by making it sustainable fact. If we have to do the reverse way: Sovereign person on top, after spreading on the whole society and each individual (citizen) in particular. For this reason the contract is mediation in terms of conversion to natural condition in civil society and natural mankind in citizen. In a schematicall way it would appear 




Fig. 2

\section{Fig. 2}

Even so, Pufendorf, the theory of contract sought to lead further, by seeing the viewpoint of Hobbes for the social contract as too submissive and not enough. If for Hobbes it is just a social contract, for Pufendorf as a professional jurist is needed "two agreements and a decree. . ." (Pufendorf 2007, 184). The first is the agreement of free men by nature, who gather by create a contractual relationship between each other - turning from a state of natural sociality "... in one sinlge union and permanent. . . with advice and common guidance; Well, they want to be co-nationals " (Pufendorf, 2007, p. 184). In contrast to Hobbes, for Pufendorf, minimum accountability in terms of natural sociality already is specified what to do and not to do. In this contract, everyone in particular, by creating the unity of the whole agree to create a new stage of society. Here is expressed between members of society to consolidate the relations between them, therefore, so to lead the natural sociality in a more organized stage. Here the society expresses as a single body. So, the initial contract consists in the agreement to create a more consolidated level of the natural sociality, emphasizing the duties, clarifies the responsibilities and hence in creation of civil society, where each member is part of the community, it is fellow citizen. Pufendorf emphasizes that power that finds its source in the voluntary union of individual forces. Even though, in a different concept from Hobbes, Pufendorf believes in a formed body, which represent the strengthest force than every other power, and this is the power of all ". . . namely the state (civitas) " (Pufendof, 2007, p. 184). Through a decree this social body as an objective unity determines the form of organization and the way of governing. Thereafter, is need another contract which determines who must be the individuals who deserve this power of the whole. From this moment, the second contract determines the nature and the profile of the person with sovereign power.

Just like Hobbes, even in the judgment of Pufendorf, the contract is an act of exchange not just material, but exchange (converter) of status, human attributes. Person accepts to give up some freedom and rights in the natural condition and in principle (theory) these to delegate the person with Sovereign Power, who cares for further consolidate natural sociality. From the deal, as we said society members commit to undertake tasks which arises now not as individuals, but as a citizen (citizen), which means obeying the created power, and from the other side in bases of exercising the power is the obligation to ensure the safety and tranquility of society, in funcrion of natural law that every single individual enjoys (Pufendorf 2007, 184).

In a schematicall way, Pufendrof viewpoint will appear in this form: 


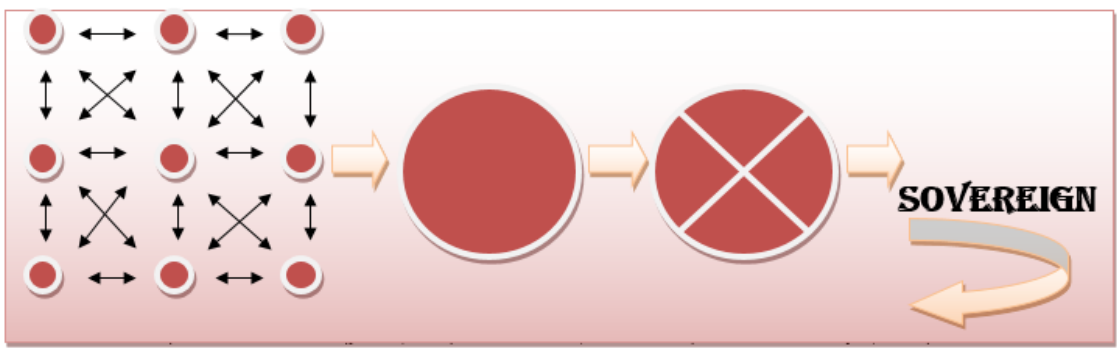

Kontrata shoqërore $\rightarrow$ (Bashkësia qytetare (Civitas) $\rightarrow$ Dekreti (Forma e Shtetit) $\rightarrow$ Kontrata e dytë (Sovrani)

\section{Fig. 3}

Reverse path is in the same view as that of Hobbes. But here remains to be evidented the difference that social body in judgment of Pufendorf's hides the individual. He mostly implied, in meltingwith the whole. According to this judgment, the sovereign and the subject lose the directly report. Mediator for the individual is the civil society where is placed in report to the Sovereign, in case when the Sovereign act over the individual the mediator is the state. At this point it seems that civil society and the state identify each - other. Schematically reverse way would be like this form:

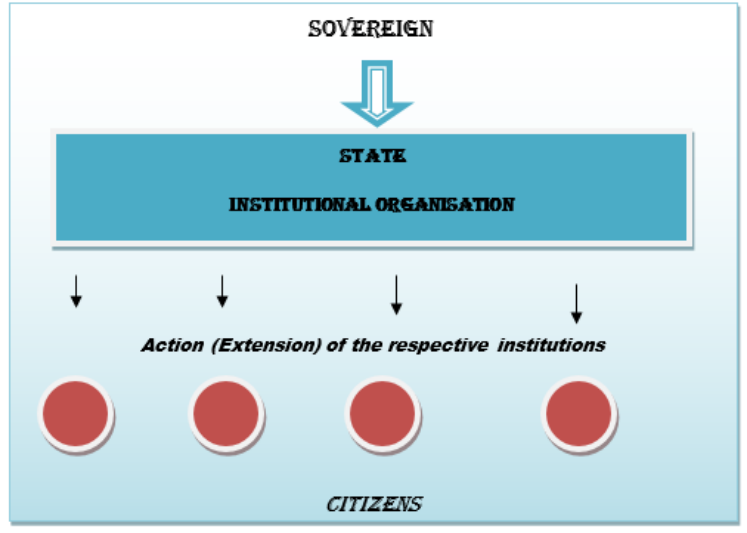

Fig. 4

\section{Post - contract: the nature, extention and characteristics of the Sovereign}

Mediator role of the contract makes possible the process of passing from the freedom or uncondicional state in circumstances of absolute duties. Freedom for man after the contract is expressed more limited, as a minimum space of action (Hobbs, 2000, p. 97). Avoiding the natural condition and willpowergness (accountability) to enter in the civil society is an indication that the contract is not only intermediary, but it is untouchable, absolutely inviolable (Hobbes, 2000, p. 98). Inviolability and undifferentiabe of this contract, in the judgment of Hobbes, means that the sovereign power is absolute, untachable, unaltered. From this comparison, but even started from the meaning that Hobbes gives to the social contract, as an absolute converter, from the absolute freedom to the absolute duty we will express for a sovereign power that subdues, but in an absolute way.

Social pact means that we have determined the reference, the criteria on the actions and behavior of everyone. Now and on, the particular individual is not anymore arbiter of its actions. The sovereign in this discur is a necessary condition to society. Differently from Pufendorf he sees the politic body and the civil organization of the society with a governing power as the only meaning of the term "society". Sovereign power is the fundamental criterion of society creation. People by nature are asocial, and even don't have any inclination or desire, pleasure to live in society (Hobbs, 2000, p. 78). This criterion gives validity and regulates relations among the members. Order with Sovereign power it gives meaning even to 
the politic body or creates the nature of civil society. In short, the absolutism of Hobbes sees meaning over society, the political body or civilian society as fundamentally inseparable with sovereign power.

Pufendorf concepts somehow different Hobbesian premise, where the possibility of the bad and maintenance of natural sociality will conclude through contract in a sovergein power, which absolutize only the safety and guaranty of natural law, not interested at all for forms or other actions, which dosn't violate this principle, so differently from Hobbes, where at Sovereign everything is absolutised. Perhaps here we have a tendency to express a sovereign with reduced expandation, anticipating the political liberalism with the idea of "minimal state". Pufendorf in the reason of sovereign power absolutize only the foundamentals of natural laws allowing the moral and the authentic sociality in their simplicity until unencroachment of this that makes the principle of natural law. So, Pufendrof differ the sociality from civil society (citizen), where the reason of the last makes the reason of Sovergein Power, as the above reason, the most cultivated.

Natural liberty like duty and right, in the judgment of Pufendorf is a wide concept and the reason of Sovereign power is included by this concept by referring to specific aspects, henceforth creating the other level of social organizing (Pufendorf, 2007 , p. 25). Viewed from this point, the civil right unless it contradicts the natural law is within the application criteria and its applicability (similarity with Bodin). While in Hobbes, civil law must change the natural condition like a total bad, to ensure the fulfillment of human nature as an individual. In the condition of absolute freedom and absolute right in the natural condition in terms of duty, the Sovereign law. Levitani for him is an artificial body, which creates an artificial society (remember sociality is unnatural for Hobbes), with the primary aim of meeting the foundamental natural law, human survival. For this reason, the sovereign power should include the whole, therefore be absolute.

After the Social Contract, we are in a different context. Individuals are not yet a crowd as Hobbes describes, nether a natural sociality state (spontaneous) as it deems Pufendorf. Already they through contract are consolidating as a single body, as a unique political community by objecivising the force (powers) of individual at soverign person, who is personification of this unified body, So, the sovereign doesn't represent simply society, but a given concept of it, which is related to safety, the compacticy of organization. Thanks to this change, we have the passing from chaotic state or natural sociality in social society, which makes more stable human relationships to clear and strict rules. In this context, the contract and its implementation is the avoidance of the natural bad and this is a rule of reason to avoid being destroyed or selfdestroyed.

Anyway, here are showed two models of contracts. The contract of Pufendorf creates the Sovregein power, differently from Hobbes where the Sovereign is contracted. In the philosophy of Pufendorf, power is generated, created, formed by the "agreement", as a joint act, as internal community act. To Hobbes, the power of all is personified to a single individual, as a third party, by supporting the monarchy form of governance. The absolute power, inalienable that act to all, but without losing the individual connection (contract) with no one. Hobbesian contract creates a direct connection between the subject and Sovereign in a comprehensive context (public). Connection which in Pufendorf's is missing where mostly the individual delegates the right and responsibility to the community and the contracted community decides about sovereign power. How to say, the individual has indirect relationship with sovereign power. In this case, is more expressed an institutional form of Sovereign, giving the state importance as a way of extending this power. However, not clearly Pufendorf seem inclined to institutional Monarchy of governance or Republic form.

In this context, State for Pufendorf is seen as a "moral person" (Pufendorf 1964, p. 11). The double contract is not simply an act that creates individual reports between subjects and the Sovereign Person, like happens in contract of Hobbes. So, Sovereign doesn't contract, but is created based on the opinion of Pufendorf, where the community as a social body, organized politically delegates all his power to the Sovereign Person by distancing from the physic person in public person (Beaulac, 2003, p. 254). His action does not come in direct way as power of physic person over the members of society. Extension is mediated by the state, the shape of which is expressed in decree, by giving moral and public character, motivated by the creation of civic community thanks to the initial contract.

As the representative of all, the Sovereign except he wins omnipotence, he is completely free, as a separate entity, situated outside the society, but in function of it. So, he is discerned, separated and attributed virtue, quality, rights and duties that do not belong to anyone in particular. In the logic of Hobbes, it is the person who represents the society as a single body, consolidates and organizes it, even though it is not subject (member) of the society, consequently, nor subject to his power. Argument justifies the Sovereign as a higher power and absolutely unrestricted by other powers. Being, seperatly entity the sovereign acquires a quite special status, which for Hobbes does not even have comparance with the individual, nor with 
one part of society, not even with concrete society taken as whole. Characteristic described even by Pufendorf (Pufendorf, 2007, p. 185).

\section{Conclusions}

Invulnerability of some natural rights, fundamental like the one of life requires assurance and guarantee for the applicability of this principle, even this goes beyond the humanism expressed in the philosophy of Pufendorf. State of Nature is the premise from which initiates a conversion process (exchange) and the contract is the point of connection, intermediary moment. In this context, the contract is not only the main point of the transformation of human society from natural situation, but it is also special because it of moral character, social and political. Hence, it creates an artificial Person with legal attributes. So, the social contract is something intermediate between the socio - political act and legal convention. Just so, one can justify the other. How to say, the socio - political act in terms of post - contract is dictated by the legal rule and vice versa, the legal act is justified by socio - political pact.

The difference to both authors comes as a result of different ways in concepting of the same premsië, such as the state of nature. Hobbes concepts it as a total chaos, like a state of absolute bad, where all are characterized by ego and private interest. Therefore, the contract should make an absolute conversion from the conditions of freedom in terms of duties. In this sense, the society beyond the contract, civil society, for Hobbes is the opposite of state of nature. Society has meaning only like a civil society, which, refers to a completely absolute power, as Sovereign (King). Discussion, which Pufendorf do it differently, where natural condition, without excluding the arguments of Hobbes, is not characterized by total bad, but from the possibility of bad. Man, by nature tends towards the community with others. For this reason, the Social Contract of Pufendorf is sequel of the state of nature as a kind improvement of itself, as a kind improved. It fixes, absolutise only the laws of nature through the guarantee of power sovereign.

Hobbesian contract is one and only, which focuses on dacordness among members to authorise (delegate) their power to a third Person. So, this model contract consists in individual authorization (personal) of power to a person made in a public context, such is social contract. Pufendorf thinks differently this moment; with two contracts and one decree, where the first contract forms civic community and this community through decree proclaimed the form of government, going further with a second contract, which defines the Sovereign Person. So, at Hobbes we have direct relation between the individual and the Sovereign, and to Pufendorf individual hides through civic community. This creates the difference in the way of action of the Sovereign on citizens, where to Hobbes is in the same time on everyone and anyone in particular, but for Pufendorf the exctention of sovereign power is realized through the State, as an inclusive and public.

\section{Bibliography}

[1] Aristoteli, "Politika", "Plejad", Tiranë 2003

[2] Beaulac. S, "Emer de Vattel and the Externalization of Sovereignty", Journal of the History of International Law, Koninklijke Brill NV. Printed in the Netherlands, pp: 237 - 292, 2003

[3] Bodin. J, "Sovraniteti", ISP\&Dita 2000, Tiranë 2007

[4] Hobbes. T, "De Cive or The Citizen", Appleton-century-crofts incorporated New York 1949, Digitized by the Internet Arcive in 2011 with funding from LYRASIS IVI embers and Sloan Foundation

[5] Hobbes. T, "Leviatani", IPS\&Dita 2000, Tiranë 2000

[6] Palladini. F, "Pufendorf disciple of Hobbes: "The nature of man and the state of nature: The doctrine of socialitas", History of European Ideas, pp; 26 - 60, 2008

[7] Platoni, "Republika”, Phoenix, Tiranë 1999

[8] Pufendorf. S, "Detyra e njeriut dhe e qytetarit sipas ligjit natyror", ISP \& Dita 2000, Tiranë 2007

[9] Pufendorf. S, "De officio hominis et civis juxta legem naturalem libri duo", Vol II, transl. F. G. Moore, Oceana Publications, London - New York 1964

[10] Tuck. R, "Hobsi, një hyrje e shkurtër", Ideart, Tiranë 2008 